\title{
Jurist-Diction
}

Volume 4 No. 6, November 202

\section{Analisis Keabsahan Pembacaan Putusan Pidana yang Dibacakan Secara Virtual atau Elektronik}

\author{
Angelia Dwi Oktavia \\ Angelia.dwi.oktavia-2017@fh.unair.ac.id \\ Universitas Airlangga
}

How to cite:

Angelia Dwi Oktavia, 'Analisis Keabsahan Pembacaan Putusan Pidana yang Dibacakan Secara Virtual atau Elektronik' (2021) Vol. 4 No. 6 Jurist-Diction.

Histori artikel:

Submit 9 Agustus 2021;

Diterima 15 Oktober 2021;

Diterbitkan 5 November 2021.

DOI:

10.20473/jd.v4i6.31840

p-ISSN: 2721-8392

e-ISSN: 2655-8297

\section{Abstract}

The use of teleconferencing facilities in courts in Indonesia is actually not an absolute new thing. Long before, the model for examining witnesses with the help of multimedia technology was first carried out in 2002. However, teleconferencing has not been recognized in the Criminal Procedure Code, because at the time the Act was enacted it could not be practiced. Regarding reading the decision by teleconference, there has also been no reading regarding whether it is legal or not. The formulation of the problem reviewed in this study is whether reading a criminal verdict read out virtually or electronically is against Article 195 of the Criminal Procedure Code. The research method used is legal research with an approach and an approach to laws and regulations to examine existing legal problems. The results of this research can be seen that reading a criminal reading that is read out virtual or electronically does not conflict with Article 195 of the Criminal Procedure Code because it refers to the principle of Salus Polupi Suprema lex Esto and refers to the relevant laws.

Keywords: Trial; Teleconference; Decision.

\begin{abstract}
Abstrak
Penggunaan sarana teleconference di dalam persidangan di Indonesia sebenarnya bukan merupakan hal yang mutlak baru. Jauh sebelumnya, model pemeriksaan saksi dengan bantuan teknologi multimedia pertama kali dilakukan pada tahun 2002. Tetapi teleconference belum diakui dalam Kitab Undang-Undang $\neg$ Hukum Acara Pidana, karena pada masa Undang-Undang dibuat hal demikian itu tidak dapat dipraktikkan. Terkait dengan pembacaan putusan pidana secara teleconference juga belum ada kejelasan terkait sah atau tidaknya. Rumusan masalah yang diulas dalam penelitian ini adalah apakah pembacaan putusan pidana yang dibacakan secara virtual atau elektronik bertentangan dengan Pasal 195 KUHAP. Mmetode penelitian yang digunakan adalah legal research dengan melalui pendekatan konseptual dan pendekatan peraturan perundangundangan untuk mengkaji permasalahan hukum yang ada. Hasil dari penelitian tersebut dapat diketahui bahwa pembacaan putusan pidana yang dibacakan secara virtual atau elektronik tidak bertentangan dengan Pasal 195 KUHAP karena mengacu kepada asas Salus Polupi Suprema lex Esto serta mengacu kepada Undang-Undang yang terkait. Kata Kunci: Persidangan; Teleconference; Putusan.
\end{abstract}

Copyright $(\subset 2021$ Angelia Dwi Oktavia 


\section{Pendahuluan}

Saat ini dunia sedang menghadapi wabah Coronavirus Disiase-19 (COVID-19). Virus ini dapat menyerang siapa saja. Seperti lansia (golongan lanjut), orang dewasa, anak-anak, bayi, termasuk ibu menyusui atau ibu hamil. Infeksi Coronavirus Disiase-19 pertama kali ditemukan dikota wuhan, china. Virus ini menular dengan sangat cepat dan telah menyebar ke hampir semua negara, termasuk Indonesia hanya dalam waktu beberapa bulan. Untuk mengurangi penyebaran pandemi Covid-19, beberapa negara memberlakukan kebijakan lockdown. Di Indonesia sendiri diberlakukannya kebijakan Pembatasan Sosial Berskala Besar (PSBB).

Pembatasan Sosial Berskala Besar (PSBB) dilakukan Indonesia untuk mempercepat penganggulangan dan mencegah penyebaran Corona virus yang semakin meluas di Indonesia. Degan diberlakukannya kebijakan Pembatasan Sosial Berskala Besar (PSBB) semua orang diharapkan untuk mampu menahan diri agar tidak berinteraksi secara langsung dengan pihak lain. Dengan itu, pemerintah menghimbau agar masyarakat melakukan social distancing. Terdapat beberapa hal yang dibatasi selama PSBB yaitu : membatasi aktivitas sekolah dan tempat kerja, membatasi kegiatan keagamaan yang dapat menimbulkan berkerumunnya orang, membatasi kegiatan yang diselenggarakan di tempat umum atau fasilitas umum, membatasi kegiatan sosial dan budaya yang dapatmenyebabkan kerumunan orang, dan membatasi jumlah penumpang pada transportasi umum.

Meningkatnya penyebaran Corona Virus Disiase (Covid-19) dan diberlakukannya kebijakan Pembatasan Sosial Berskala Besar (PSBB) serta Social Distancing, membawa dampak pada lembaga peradilan. Mahkamah Agung terpaksa menerapkan kebijakan bekerja atau melaksanakan tugas kedinasan dari rumah (Work Form Home)bagi para hakim dan aparatur peradilan secara bergantian. Dalam keadaan yang mendesak tersebut (ForceMajeur), pengadilan juga harus melaksanakan persidangan secara online jarak jauh atau Teleconference. Mahkamah Agung juga memiliki respon cepat terkait keadaan pandemi saat ini, yaitu mengeluarkan Surat Edaran Mahkamah agung No. 1 Tahun 2020 tentang Pedoman Pelaksanaan Tugas Selama Masa Pencegahan Penyebaran Corona Virus 
Disease 2019 (COVID-19) di Lingkungan Mahkamah Agung Dan Badan Peradilan Dibawahnya yang selanjutnya dirubah menjadi Surat Edaran Mahkamah Agung No. 3 Tahun 2020, kemudian dirubah kembali menjadi Surat Edaran Mahkamah Agung No. 4 Tahun 2020. Surat Edaran tersebut merupakan dasar hukum untukpenyelenggaraan persidangan secara onlinejarak jauh atau teleconference. Hal tersebut dilandaskan pada asas Salus Populi Suprema Lex Esto yang artinya Keselamatan Rakyat Adalah Hukum Tertinggi.

Pada tanggal 27 Maret 2020 MA melalui Dirjen Badilum juga telah mengeluarkan Surat Nomor 379/DJU/PS.00/3/ 2020 tentang persidangan perkara pidana secara Teleconference. Dalam surat tersebut, Dirjen Badilum menyampaikan kepada Pimpinan Pengadilan Tingkat Banding dan khususnya Pengadilan Tingkat Pertama bahwa selama masa pandemic covid-19 persidangan perkara pidana dapat dilakukan secara jarak jauh atau teleconference. ${ }^{1}$

Poin III Huruf C Surat Edaran Ketua Pengadilan Tinggi DKI Jakarta Nomor w10/01/kp.05.1/3/20 (SEKPT DKI) mengatur Khusus untuk perkara pidana yang terdakwanya ditahan selama masa darurat ini, persidangan dapat dilakukan melalui teleconference, dengan cara:

1. Pembacaan dakwaan dilakukan dengan cara hakim, panitera pengganti, penuntut umum dan penasihat hukum terdakwa berada di ruangan sidang pengadilan yang menyidangkan perkara tersebut.

Terdakwa berada di ruangan khusus tahanan yang dilengkapi dengan fasilitas teleconference, sehingga pembacaan dakwaan didengar oleh terdakwa dan dapat menentukan sikap/memberikan tanggapan setelah berkomunikasi dengan penasihat hukumnya apakah mengajukan eksepsi atau tidak mengajukan eksepsi;

2. Pemeriksaan saksi dilakukan dengan cara saksi didengar di muka persidangan yang didengar oleh terdakwa yang berada di ruangan khusus di rumah tahanan negara/lembaga pemasyarakatan;

3. Pemeriksaan terdakwa, pembacaan tuntutan, pembelaan dan pembacaan putusan dilakukan melalui teleconference;

4. Apabila tidak terdapat fasilitas teleconference di rumah tahanan negara dan/atau lembaga pemasyarakatan, maka persidangan tetap diupayakan dilaksanakan secara biasa (tidak melalui teleconference).

${ }^{1}$ Wahyu Iswantoro, 'Persidangan Pidana Secara Online, Respon Cepat MA Hadapi Pandemi Covid-19' (2020) Volume 6 Selisik.[6]. 
Pelaksanaan persidangan secara virtual/elektronik pada pemeriksaan perkara di Indonesia bukanlah hal yang baru. Sebelum adanya pandemi Covid-19, di Indonesia sudah menerapkan penyelesaian perkara melalui video converence. Namun penggunaannya hanya terbatas untuk mendengarkan saksi. Hal ini sebagaimana diatur dalam Pasal 9 Ayat (3) UU Nomor 31 tahun 2014 tentang Perubahan Atas UU Nomor 13 Tahun 2006 tentang Perlindungan saksi dan korban, dimana seorang saksi dapat didengar kesaksiannya secara langsung melalui sarana elektronik dengan didampingi oleh pejabat yang berwenang. Penggunaan video converence ini bertujuan untuk melindungi keamanan saksi dari berbagai ancaman atau demi mempermudah pemberian keterangan tanpa harus hadir di ruang sidang. Sementara itu pihak-pihak lain seperti hakim, penuntut umum, terdakwa dan pengacaranya tetapdiwajibkan hadir diruang sidang berdasarkan ketentuan peraturan perundangundang penggunaan video converence ini. ${ }^{2}$

Dengan tidak diubahnya Undang-UndangNomor 8 Tahun 1981 tentang Hukum Acara Pidana (KUHAP) yang didalamnya mengatur tentang sistem peradilan pidana di Indonesia, maka sangat sulit untuk dilaksanakannya praktik persidangan secara virtual/elektronik.Perjanjian kerjasama antara Mahkamah Agung RI, Kejaksaan RI dan Kementrian Hukum dan HAM tidak memiliki landasan hukum yang cukup kuat bahkan ada yang mengatakan bertentangan dengan peraturan perundang-undangan yang lebih tinggi, yaitu KUHAP. Pada Pasal 195 KUHAP menyebutkan bahwa "semua putusan pengadilan hanya sah dan mempunyai kekuatan hukum apabila diucapkan di sidang terbuka untuk umum”.

\section{Metode Penelitian}

Penelitian dilakukan secara normatif. Pendekatan terhadap masalah dilakukan melalui Pendekatan peraturan perundang-undangan (Statute Approach) dan Pendekatan konseptual (conceptual approach).

\footnotetext{
${ }^{2}$ Aristo M.A Pangaribuan, Arsa Mufti, dan Ichsan Zikry, Pengantar Hukum Acara Pidana di Indonesia (Raja Grafindo 2017).[245].
} 


\section{Pembacaan Putusan Pidana Secara Teleconference}

Suatu perkara pidana dapat dikatakan berakhir atau selesai jika hakim telah mengeluarkan suatu putusan. Dalam memutus suatu perkara, hakim perlu memeriksa dan memahami unsur-unsur tindak pidana yang didakwakan. Ketika hakim menyatakan pemeriksaan ditutup, selanjutnya hakim akan mengadakan musyawarah untuk menyiapkan suatu putusan. Bentuk putusan yang akan dijatuhkan oleh pengadilan tergantung hasil musyawarah para hakim yang bertitik tolak dari surat dakwaan dengan segala sesuatu yang terbukti dalam pemeriksaan di sidang pengadilan.

Pada pasal1 Undang-Undang No 8 tahun 1981 tentang Hukum Acara Pidana (KUHAP) yang didalamnya mengatur tentang sistem peradilan di indonesia, menjelaskan tentang apa itu putusan pengadilan.Putusan pengadilan adalah pernyataan hakim yang diucapkan dalam sidang pengadilan terbuka yang dapat berupa pemidanaan atau bebas atau lepas dari segala tuntutan hukum dalam hal serta menurut cara yang diatur dalam undang-undang ini. ${ }^{3}$

Putusan yang akan dijatuhkan pengadilan mengenai suatu perkara, bisa berbentuk:

1. Putusan bebas, berarti terdakwa dinyatakan bebas dari tuntutan hukum (Vrij spraak). Hal ini diatur dalam Pasal 191 (1) KUHAP yang menyatakan bahwa tidak terbukti adanya kesalahan dan tidak adanya dua alat bukti yang terpenuhinya unsure tindak pidana;

2. Putusan lepas dari segala tuntutan hukum, kalau putusan pembebasan diatur dalam Pasal 191 ayat (1) maka putusan pelepasan dari segala tuntutan hukum diatur dalam Pasal 191 ayat (2), yang berbunyi: “jika pengadilan berpendapat bahwwa perbuatan yang didakwakan kepada terdakwa terbukti, tetapi perbuatan itu tidak merupakan suatu tindak pidana maka terdakwa diputus lepas dari segala tuntutan hukum". ${ }^{4}$ Inti dari putusan ini adalah terdakwa terbukti, tetapi bukan tindak pidana, adanya alasan pemaaf, pembenar, atau bisa juga keadaan darurat;

3. Putusan pemidanaan, bentuk putusan pemidanaan diatur dalam Pasal 193. Pemidanaan berarti terdakwa dijatuhi hukuman pidana sesuai dengan ancaman yang ditentukan dalam pasal tindak pidana yang didakwakan kepada terdakwa. Sesuai dengan Pasal 193 ayat (1), penjatuhan putusan pemidanaan terhadap

\footnotetext{
${ }^{3}$ Undang-Undang Nomor 9 Tahun 1981 tentang Hukum Acara Pidana.

${ }^{4}$ M. Yahya Harahap, Pembahasan Permasalah dan Penerapan KUHAP (Sinar Grafika 2000).[331].
} 
terdakwa didasarkan pada penilaian pengadilan. Jika pengadilan berpendapat dan menilai terdakwa terbukti bersalah melakukan perbuatan yang didakwakan kepadanya, pengadilan menjatuhkan hukuman pidana terhadap terdakwa. ${ }^{5}$ Setelah putusan dibacakan, hakim memberitahukan kepada terdakwa bahwa ia (terdakwa) memiliki hak untuk menerima, pikir-pikir, atau banding;

4. Penetapan tidak berwenang mengadili, kemungkinan bisa terjadi sengketa mengenai wewenang mengadili terhadap suatu perkara. Pada Pasal 147 KUHAP mengingatkan kepada Pengadilan Negeri bahwa setelah menerima surat pelimpahan perkara dari penuntut umum, tindakan pertama yang perlu dilakukan adalah mempelajari berkas perkara; ${ }^{6}$

5. Putusan yang menyatakan dakwaan tidak dapat diterima, ini berpedoman pada Pasal 156 ayat (1) KUHAP;

6. Putusan yang menyatakan dakwaan batal demi hukum, halini diatur dalam pasal 143 ayat (3) dan Pasal 156 ayat (1). Jika pasal tersebut dihubungkan Pengadilan Negeri dapat menjatuhkan Putusan yang menyatakan dakwaan batal demi hukum baik itu karena permintaan terdakwa/ penasehat hukumnya dalam eksepsi ataupun karena wewenang hakim dalam jabatannya.

Tata cara pembacaan putusan pidana:

a) Hakim ketua perlu menjelaskan bahwa acara sidang hari ini adalah pembacaan putusan, tetapi sebelum putusan dibacakan hakim ketua meminta agar para pihak yang hadir supaya memperhatikan isi putusan dengan seksama.

b) Selanjutnya, Hakim ketua mulai membaca isi putusan. Tata caranya sama dengan pembacaan putusan sela (bila naskah putusan terlalu pajang maka boleh di bacakan ole hakim anggota secara bergantian).

c) Setelah hakim membacakan isi putusan, tibalah saatnya hakim akan membacakan amar putusan. Sebelum memulai membaca/mengucapkan kata "mengadili" Hakim ketua memerintahkan agar terdakwa berdiri di tempat.

d) Setelah amar putusan dibacakan seluruhnya kemudian Hakim ketua mengetuk palu(1x)dan mempersilahkan terdakwa untuk duduk kembali.

e) Hakim ketua perlu menjelaskan isi putusan secara singkat terutama yang berkaitan dengan amar putusan hingga terdakwa paham terhadap putusan yang di jatuhkan padanya.

f) Setelah itu, hakim ketua menjelaskan hak-hak dari para pihak terhadap putusan tersebut. selanjutnya hakim ketua menawarkam kepada terdakwa untuk menentukan sikapnya, apakah menerima putusan tersebut,mengajukan grasi,naik banding atau menyatakan pikir-pikir. Dalam hal ini terdakwa diberi waktu sejenak untuk berkonsultasi dengan penasehat hukumnya atau terdakwa mempercayakan haknya kepada penasehat hukumnya,hal yang sama juga di tawarkan kepada penuntut umum jika terdakwa/penasehat hukum menyatakan sikap menerima,maka hakim ketua meminta terdakwa agar segera

\footnotetext{
${ }^{5}$ M. Yahya Harahap,Op.Cit.[333].

${ }^{6}$ Undang-Undang Nomor 8 Tahun 1981 Tentang Hukum Acara Pidana.
} 
menandatangani berita cara pernyataan menerima putusan yang telah disiapkan oleh panitra pengganti. Tetapi, jika terdakwa menyatakan banding maka terdakwa segera diminta untuk menanda tangani akta permohonan banding,jika terdakwa/penasehat hukum pikir-pikir dulu,maka hakim ketua menjelaskan bahwa masa pikir-pikir diberikan selama tujuh hari,apabila setelah tujuh hari terdakwa tidak menyatakan sikap maka terdakwa di anggap menerima putusan. Hal sama juga dilakukan terhadap penuntut umum.

g) Apabila tidak ada hal-hal yang akan di sampaikan lagi maka hakim ketua menyatakan seluruh rangkaian acara persidangan perkara pidana yang bersangkutan telah selesai dan menyatakan sidang di tutup. Tata caranya adalah: setelah mengucapkan kata-kata "....sidang dinyatakan di tutup"hakim ketua mengetuk palu sebanyak tiga kali.

h) Panitra pengganti mengumumkan bahwa majelis hakim akan meninggalkan ruangan sidang. Para pihak yang hadir di ruangan sidang tersebut diminta untuk berdiri termasuk Jaksa Penuntut Umum, terdakwa/ penasehat hukum.

i) Hakim/majelis hakim meninggalkan ruang sidang melalui pintu khusus,

j) Para pengunjung sidang,penuntut umum penasehat hukum dan terdakwa berangsur-angsur meninggalkan ruang sidang.Apabila putusan menyatakan terdakwa tetap di tahan,maka pertama-tama keluar adalah terdakwadengan dikawal oleh petugas.

Untuk pembacaan putusan pidana secara teleconference hampir sama dengan pembacaan pidana secara konvensional atau biasa, bedanya disini adalah para pihak tidak dalam satu ruangan. Hakim, panitera pengganti, penuntut umum dan penasehat hukum berada di ruang sidang pengadilan yang menyidangkan perkara tersebut. Dan terdakwa berada di ruang khusus tahanan yang dilengkapi dengan fasilitas teleconference.

\section{Pembacaan Putusan Pidana Secara Teleconference Jika Dikaitkan Dengan Pasal 195 KUHAP (Asas peradilan terbuka untuk umum).}

Memperhatikan bunyi ketentuan Pasal 195 KUHAP "semua putusan hanya sah dan mempunyai kekuatan hukum apabila diucapkan di sidang terbuka untuk umum" dapat diambil pengertian: Sahnya putusan serta supaya putusan mempunyai kekuatan hukum, harus diucapkan di sidang pengadilan "yang terbuka untuk umum,"Putusan yang diucapkan dalam "sidang tertutup," dengan sendirinya "tidak sah" dan tidak mempunyai kekuatan hukum yang mengikat. Oleh karena itu, 
putusan yang diucapkan secara tertutup tidak mempunyai daya eksekusi. ${ }^{7}$

Dasar dari pemikiran Pasal 195 yang menentukan asas putusan harus diucapkan dalam sidang pengadilan terbuka untuk umum ini terkadung dalam Pasal 153 ayat (3) antara lain : untuk menjamin tegaknya perlindungan hak asasi terdakwa dalam suatu persidangan, untukmenjamin terciptanya peradilan yang jujur, dan untuk menghindari proses dan perlakuan yang sewenang-wenang dariaparat penegak hukum yang mengadili perkara.

Asas peradilan terbuka untuk umum atau yang biasa dikenal dengan "asas demokrasi" atau "asas transparansi" memberikan makna yang mengarah kepada tindakan penegak hukum di Indonesia serta penerapan sistem musyawarah dan mufakat oleh majelis peradilan dalam mengambil keputusan harus dilandasi dengan jiwa "persamaan" dan "keterbukaan”. Artinya tidak boleh ada rahasia segala sesuatu yang bersangkutan dengan pemeriksaan mulai dari penyidikan, terhadap tersangka atau terdakwa.

Pada saat majelis hakim hendak membuka sidang, harus menyatakan "sidang terbuka untuk umum". Setiap orang yang hendak mengikuti jalannya persidangan, dapat hadir memasuki ruangan sidang. Pintu dan jendela ruangan sidang pun terbuka, sehingga dengan demikian makna prinsip persidangan terbuka untuk umum benar-benar tercapai. ${ }^{8}$

Beberapa Pasal yang digariskan untuk mempertegas tindakan tentang asas peradilan terbuka untuk umum adalah:

1.) Pemeriksaan di sidang pengadilan terbuka untuk umum (Pasal 153 ayat (3)) jadi, pada saat membuka persidangan pemeriksaan perkara seseorang terdakwa, hakim ketua harus menyatakan "terbuka untuk umum". Pelanggaran atas ketentuan ini atau tidak terpenuhinya ketentuan ini mengakibatkan putusan pengadilan "batal demi hukum" (Pasal 153 ayat (4)). Tentu terhadap ketentuan ini ada kecualinya sepanjang mengenai perkara yang menyangkut "kesusilaan"

${ }^{7}$ M. Yahya Harahap, Pembahasan Permasalahan dan Penerapan KUHA (Sinar Grafika 2017).[357].

${ }^{8}$ ibid. 
atau yang duduk sebagai terdakwa terdiri dari "anak-anak". Dalam hal ini persidangan dapat dilakukan dengan "pintu tertutup". 9

2.) Pasal 64 KUHAP juga menyatakan bahwa "tersangka atau terdakwa berhak diadili di sidang pengadilan yang terbuka untuk umum”.

3.) Pasal 13 Undang-Undang Nomor 48 Tahun 2009 tentang Kekuasaan Kehakiman

(UU Kekuasaan Kehakiman) yang berbunyi: ${ }^{10}$

1. semua sidang pemeriksaan pengadilan adalah terbuka untuk umum, kecuali Undang-Undang menentukan lain.

2. Putusan Pengadilan hanya sah dan mempunyai kekuatan hukum apabila diucapkan dalam sidang terbuka untu umum.

3. Tidak dipenuhinya ketentuan sebagaimana dimaksud pada ayat (1) dan ayat (2) mengakibatkan putusan batal demi hukum.

Jika hakim menyatakan sidang tertutup untuk umum berdasarkan Pasal 195 KUHAP hal seperti itu menjadikan putusan batal demi hukum. Karena isi pasal tersebut adalah "semua putusan pengadilan hanya sah dan mempunyai kekuatan hukum apabila diucapkan di sidang terbuka untuk umum”.

Adapun pengecualian yang dimaksud oleh undang-undang adalah, antara lain:

1. Pasal 70 ayat (2) Undang-Undang ketentuan Pasal 70 ayat (2) Undang-Undang Nomor 5 Tahun 1986 tentang Peradilan Tata Usaha Negara (UUPTUN) yang menyatakan Apabila Majelis Hakim memandang bahwa sengketa yang disidangkan menyangkut ketertiban umum atau keselamatan negara, persidangan dapat dinyataan tertutub untuk umum. ${ }^{11}$

2. Pasal 80 ayat (2) Undang-Undang Nomor 7 Tahun 1989 tentang Peradilan agama (UUPA) yang menyatakanpemeriksaan gugatan perceraian dilakukan dalam sidang tertutup. ${ }^{12}$

3. Pasal 141 ayat (3) Undang-Undang Nomor 31 Tahun 1997 tentang Peradilan Militer (UUDILMI) menjelaskan tetntang rahasia militer, bunyinya adalahdalam perkara yang menyangkut rahasia militer dan/atau rahasia negara, Hakim Ketua dapat menyatakan sidang tertutup untuk umum. ${ }^{13}$

4. Pasal 54 Undang-Undang Nomor 11 Tahun 2012 tentang Sistem Peradilan Pidana

\footnotetext{
${ }^{9}$ M. Yahya Harahap II,Op.Cit.[56].

${ }^{10}$ Undang-Undang Nomor 48 Tahun 2009 tentang Kekuasaan Kehakiman.

${ }^{11}$ Undang-Undang Nomor 9 Tahun 2004 tentang Peradilan Tata Usaha Negara.

${ }^{12}$ Undang-Undang Nomor 7 Tahun 1989 Tentang Peradilan Agama.

${ }^{13}$ Undang-Undang Nomor 31 Tahun 1997 tentang Peradilan Militer.
} 
Anak (UUSPPA) yang didalamnya mengatur tentang pemeriksaan perkara anak, menjelaskan Hakim memeriksa perkara Anak dalam sidang yang dinyatakan tertutup untuk umum, kecuali pembacaan putusan. ${ }^{14}$

Alasan memberikan pengecualian terhadap beberapa Pasal yang telah disebutkan diatas adalah karena perkara susila dianggap merupakan masalah yang sangat sensitive(pribadi sekali). Sehingga tidak layak untuk diungkapkan dan dipaparkan secara publik/ terbuka di muka umum. Dan merupakan suatu ketidak pantasan untuk mengekspos/membeberkan hal-hal terkait susila ataupun kehidupan rumah tangga orang yang terlibat didalamnya. Kemudian, dalam hal sidang pemeriksaan anak-anak, pemeriksaan persidangan tersebut memiliki cara khusus. Agar tidak menimbulkan kecenderungan yang bisa dijadikan dasar filosofis yang mengajarkan anak-anak untuk melakukan tindak pidana. Maka dari itu pemeriksaan perkara yang terdakwanya adalah anak-anak dilakukan dengan pintu tertutup. Karena jika terbuka untuk umum akan membawa akibat psikologi terhadap anak. Serta jika pemeriksaan dilakukan secara terbuka untuk umum anak akan mengalami goresan luka terhadap jiwa dan batinnya. Yang seolah-olah masyarakat umum telah melemparkan cemoohan dan kebencian terhadap dirinya. Atas dasar seperti itu, kita perlu mendukung pelaksanaan persidangan untuk anak tertutup.

Hakim berdasarkan jabatannya dapat mempertimbangkan apakah persidangan dapat terbuka untuk umum atau sebagaian atau seluruhnya tertutup untuk umum. Selain itu penuntut umum dan terdakwa memiliki hak dan meminta kepada hakim agar dapatnyapersidangansebagian atau seluruhnya tertutup untuk umum. Maksud dari tertutup untuk umum ini adalah persidangan dilakukan di belakang pintu tertutup, hanya pihak yang berperkara (terdakwa dan penasehat hukumnya jika ada) yang dapat hadir ke ruang persidangan. Masyarakat umum tidak boleh.

Walaupun sidang dinyatakan tertutup untuk umum, namun keputusan hakim tetap dinyatakan dalam sidang terbuka untuk umum. Hal dimaksud tercantum dalam Pasal 195 Kitab Undang-Undang Hukum Acara Pidana dengan tegas menyatakan: "semua putusan hanya sah dan mempunyai kekuatan hukum apabila diucapkan

\footnotetext{
${ }^{14}$ Undang-Undang Nomor 11 Tahun 2012 Tentang Sistem Peradilan Pidana Anak.
} 
dalam sidang terbuka untuk umum". ${ }^{15}$ ketentuan Pasal 195 ini melengkapi prinsip yang diatur dalam Pasal 153 (3) dan Pasal 64, yang menegaskan "pemeriksaaan sidang pengadilan terbuka umtuk umum(kecuali pemeriksaan perkara susila atau jika terdakwanya adalah seorang anak-anak)" tersangka atau tersakwa berhak diadili di sidang pengadilanyang terbuka untuk umum.

Keseluruhan pasal tersebut mengandung frasa pengadilan/sidang terbuka untuk umum, oleh majelis hakim ditafsirkan menjadi pengadilan yang dapat diliput oleh jurnalis atau wartawan sesuai dengan ketentuan pers dank ode etik jurnalis yang berlaku. ${ }^{16}$ Penyiaran persidangan pidana tidak dilarang dalam aturan, baik dalam UU Pers, Undang-Undang Nomor 32 Tahun 2002 tentang penyiaran dan Undang-Undang Nomor 14 Tahun 2008 tentang keterbukaan informasi publik. Dalam Pasal 4 Undang-Undang Keterbukaan Informasi Publik secara umum menyatakan bahwa setiap orang berhak mendapatkan informai publik. Informasi yang dimaksud merupakan informasi apapun, termasuk informasi dalam suatu persidangan mengenai hasil dari proses persidangan. Ketika persidangan dinyatakan terbuka untuk umum,dalam arti apa yang ada dipersidangan merupakan informasi untuk umum. Namun hal ini menjadi perdebatan bila penyampaian informasi baik media elektronik maupun non-elektronik, karena dapat mempengaruhi opini publik sebelum adanya putussan dari majelis hakim. ${ }^{17}$

Sebenarnya pembacaan putusan dengan menggunakan teleconference dalam persidangan saat ini pada dasarnya sama saja dengan cara pembacaan putusan biasa di persidangan yang dilakukan secara langsung (konvensional), yang membedakan hanyalah keberadaan terdakwa. Jika dalam pembacaan putusan biasa (konvensional) terdakwa dihadirkan secara fisik (bertatap muka) dalam ruang sidang, maka lain halnya dengan pembacaan putusan menggunakan teleconference, dimana terdakwa tidak dihadiran secara fisik (bertatap muka) di ruang yang sama dengan hakim,

${ }^{15}$ Undang-Undang Nomoe 8 Tahun 1981 Tentang Hukum Acara Pidana.

${ }^{16}$ Desak Paramita Brata, Ni Putu Rai Yuliartini, Dewa Gede Sudika Mangku, 'Tinjauan Yuridis Asas Sidang Terbuka Untuk Umum Dalam Penyiaran Proses Persidangan Pidana', (2020) 1 Komunitas Yustisia Universitas Pendidikan GaneshaI.

${ }^{17}$ ibid. 
penuntut umum, dan panitera, melainkan hanya secara virtual, sedangkan fisik terdakwa berada di ruangan atau tempat berbeda. pada prinsipnya pembacaan putusan dengan hadirnya terdakwa sebagaimana dimaksud secara fisik tetap terpenuhi dan terwujud dengan menggunakan teleconference.yang membedakan disini adalah keberadaan terdakwa.

Kemudian pembacaan putusan melalui teleconference hakim ketua sidang membuka sidang dan menyatakan sidang terbuka untuk publik/ umum melalui media internet (live steaming). Tersedianya layar di ruang sidang yang, dapat mempermudah publik yang memilikikepentingan untuk meliput ataupun menyaksikan jalannya persidangan.Hakim juga dapat memberitahu segala hak terdakwa. Jadi, penggunaan teleconference dalam pembacaan putusan perkara pidana tidaklah bertentangan dengan Pasal 195 KUHAP yang isinya terkait asas pengadilan terbuka untuk umum. Adanya penggunaan teleconference dalam pembacaan putusan perkara pidana di pengadilan merupakan suatu terobosan dibidang hukum sebagai wujud dari aktivitas manusia yang dipengaruhi oleh Teknologi Informasi dan Komunikasi (TIK).

\section{Perekaman Persidangan Perkara Pidana}

Hukum dianggap sebagai suatu hal yang universal, artinya dibelahan bumi manapun atau di negara manapun pasti memerlukan hukum, tetapi disisi lain hukum memiliki karakteristik tersendiri sesuai dengan cirri dan pertumbuhan hukum itu sendiri. ${ }^{18}$ Berdasarkan Pasal 1 ayat (3) Undang-Undang DasarNegara Republik Indonesia menyebutkan bahhwa "Indonesia adalah negara hukum". Norma hukum ialah peraturan yang dibuat oleh negara dan berlakunya dipertahankan dengan paksaan alat-alat seperti polisi, jaksa, hakim, dan sebagainya. Cirri khas dari norma ini adalah memaksa yang berasaldari luar, yakni pemerintah lewat aparatnya. ${ }^{19}$

\footnotetext{
${ }^{18}$ Hafrida, 'Perekaman Proses Persidangan Pada Pengadilan Negeri Ditinjau Dari Aspek Hukum Acara Pidana' (2014) Jurnal Ilmu Hukum.

${ }^{19}$ Suharto dan Jonaedi Efendi, Panduan Praktisi Bila Anda Menghadapi Perkara Pidana: Mulai Proses Penyelidikan Hingga Persidanga (Prenada Media Grooup 2013).[4].
} 
Sistem hukum yang dianut oleh negara Indonesia adalah sistem hukum eropa continental. Sistem hukum ini berkembang di negara-negara Eropa daratan dan sering disebut "Civil Law” yang semula berasal dari kodifikasihukum yang berlaku di kekaisaran romawi pada masa pemerintahan kaisar justinianus abad VI sebelum masehi. ${ }^{20}$ Indonesia sebagai Negara yang menganut hukum Civil Law maka yang menjadi sumber utamanya adalah Undang-Undang, dimana hukum diarahkan pada "Law as it written in the books". Dengan seperti itu, negara yang menganut sistem Civil Law maka setiapaturan dan pelakasanaan proses peradilan harus berdasarkan pada perundang-undangan yang berlaku (Kepastian Hukum). ${ }^{21}$

Hukum Acara Pidana di Indonesia diatur atau harus berdasarkan UndangUndang Nomor 8 Tahun 1981 "Kitab Undang-Undang Hukum Acara Pidana (KUHAP)". Terkait dengan proses persidangan,mulai dari prosedur standart operasional telah diatur dalam KUHAP, tepatnya dipasal 2, yang berbunyi: UndangUndang ini berlaku untuk melaksanakan tata cara peradilan dalam lingkungan peradilan umum pada semua tingkat peradilan". Adapun tujuan KUHAP dibentuk dengan tujuan: 1) untuk melindungi harkat dan martabat manusia termasuk tersangka atau terdakwa. 2) perlindungan atas kepentingan hukum dan pemerintahan. 3) Kodifikasi dan Unifikasi hukum acara pidana, 4) untuk mencapai kesatuan dan tindakan aparat penegak hukum. ${ }^{22}$

Dalam proses pelaksanaannya, untuk mewujudkan tujuan dalam proses peradilan pidana Indonesia harus berdasarkan asas. Yaitu : peradilan cepat, sederhana dan biaya ringan., Asas in Presentia, Perdilan terbuka untuk umum, persamaan hak dimuka hukum (Equality Before The Law), pengawasan oleh ketua pengadilan, praduga tak bersalah, asas ganti rugi dan rehabilitasi, asas bantuan hukum (asas Legal Assistance), asas akusator, asas formalitas, asas legalitas, asas opportunitas.

\footnotetext{
${ }^{20}$ Dedi Soemardi, Pengantar Hukum Indonesia (Ind-Hill Jakarta 1997).[73].

${ }^{21}$ Hafrida, Loc.Cit.

${ }^{22}$ Yesmil Anwar dan Adang, Sistem Peradilan Pidana, Konsep, Komponen dan Pelaksanaannyya dalam Penegakan Hukum di Indonesia (Widya Padjajaran 2009).[17].
} 
Van Bemmelen juga memberikan definisi tentang fungus hukum acraa pidana, yaitu : (1) mencari dan menemukan kebenaran, (2) pemberian keputusan oleh hakim, (3) pelaksanaan putusan. Hal yang dianggap paling penting adalah “mencari kebenaran". Setelah menemukan kebenaran yang diperoleh melalui alat bukti dan bahan bukti itulah, hakim sampai kepada putusan yang seharusnya dalam putusan itu adil dan tepatyang selanjutnya dilaksanakan oleh jaksa. A. hamzah juga memberikan defisinisi tentang hukum acara pidana, yaitu mencari kebenaran itu merupakan tujuan antara. Tujuan akhir sebenarnya adalah untuk mencapai suatu ketertiban, ketentraman, kedamaian dan kesejahteraan dalam masyarakat. ${ }^{23}$

Secara teoritis, hukum yang baik harus memenuhi unsur sosiologis, yuridis, dan filosofis dalam ilmu hukum. Demikian juga undang-undang materiil, pembuatnya tidak boleh mengesampingkan salah satunya karena ketiganya mutlak dan diperlukan, sehingga jika salah satunya dikesampingkan akan mendapatkan kendala ditenngah-tengah masyarakat. dalam hukum pidana materiil ketiga unsur tersebut sama mutlakdan diperlukan, serta dalam usaha mempertahankannya walaupun harus diikuti dengan hukum acaranya. Dalam hal ini, hukum acara disebut hukum formil dan hukum pidananya disebut hukum materiil. Hal ini dapat dibenarkan karena hukum acara pidana memiliki tujuan menemukan kebenaran materiil, mencari pelaku yang sebenarnya, kemudian meminta hakim untuk memutus tentang salah atau tidaknya pelaku yang didakwa.

Terkait dengan SEMA Nomor 4 Tahun 2012 Tentang Perekaman Persidangan jika ditinjau dari aspek tujuan hukumnya maka tidak bertentangan. Karena adanya SEMA Nomor 4 Tahun 2012 ini merupakan rangka untuk mencapai suatu tujuan dariHukum Acara Pidana tersebut. Selain itu,tujuan perekaman proses persidangan menurut SEMA Nomor 4 tahun 2012 adalah untuk memastikan pelaksanaan persidangan yang lebih transparan, akuntabel, dan teratur.

Selanjutnya, penyiaran pada pasal 1 angka 2 Undang- Undang Nomor 32 tahun 2002 adalah pemancarluasan siaran melaui sarana peancaran dan/ atau

\footnotetext{
${ }^{23}$ Hafrida, Op.Cit.[20].
} 
sarana transmisi di darat, di laut atau di antariksa dengan menggunakan spectrum frekuensi radio melalui udara, kabel, dan/ atau media lainnya untuk dapat diterma secara serentak dan bersamaan oleh masyarakat dengan perangkat penerima siaran mengingat pda prinsip atau asas persidangan terbuka untuk umum, memang tidak ada aturan yang spesifik mengenai penyiaran secara langsung (live) sidang terbuka untuk umum.

Keberadaan penayangan persidangan secara lengkap dan langsung oleh media itu merupakan bagian dari perkebangan teknologi informasi dan telekomunikasi, hal itu bisa dikatakan realitas teknologi.Persidangan secara live merupakan tafsir dari prinsip atau asas sidangterbuka untuk umum yang tercantum dalam KUHAP. ${ }^{24}$ Persidangan secara langsung (live) merupakan hak bagi terdakwa supaya dapat diadili dalam peradilan yang Fair. $^{25}$

Pada Pasal 195 KUHAP yang menyebutkan bahwa "semua putusan pengadilan hanya sah dan mempunyai kekuatan hukum apabila diucapkan di sidang terbuka untuk umum”. Bagir manan berpendapat bahwa: jika putusan itu sekali diucapkan, maka menjadi milik publik. Tidak lagi menjadi milik mereka yang berperkara saja. Karna setiap mereka yang berkepentingan berhak untuk mengetahui putusan itu. ${ }^{26}$

\section{Kesimpulan}

Pembacaan putusan pidana yang dibacakan secara virtual atau elektronik tidak bertentangan dengan Pasal 195 KUHAP yang berbunyi "semua putusan hanya sah dan mempunyai kekuatan hukum apabila diucapkan di sidang terbuka untuk umum". Karena pembacaan putusan pidana secara virtual atau elektronik tidak melanggar Asas Peradillan Terbuka Untuk Umum. Pada intinya, Pembacaan putusan pidana menggunakan teleconference dan pembacaan putusan pidana secara

${ }^{24}$ Diah Vina Laoka Boru Sitorus, IGede Artha, I Ketut Sudjana, 'Proses Persidangan Penyiaran Secara Langsung (Live) di Televisi Prespektif Hukum Acara Pidana Indonesia' (2018) Program Kekhususan Hukum Acara Fakultas Hukum Universitas Udayana.[6].

${ }^{25}$ ibid.

${ }^{26}$ Hukum online, 'Putusan pengadilan akan terbuka untuk umum', (Hukum Online 2005) http://www.hukumonline.com/berita/baca/h18500/putusan-pengadilan-akan-terbuka-untuk-umum, accesed pada 2 juni 2020. 
konvensional (biasa) sama saja. yang membedakan hanyalah keberadaan terdakwa. Jika dalam pembacaan putusan biasa (konvensional) terdakwa dihadirkan secara fisik (bertatap muka) dalam ruang sidang, maka pembacaan putusan menggunakan teleconference, terdakwa tidak dihadirkan secara fisik (bertatap muka) di ruang yang sama dengan hakim, penuntut umum, dan panitera, melainkan hanya secara virtual, fisik terdakwa berada di ruangan atau tempat berbeda. Jadi yang membedakan disini adalah keberadaan terdakwa.Selanjutnya, pembacaan putusan melalui teleconference hakim ketua sidang juga membuka sidang dan menyatakan sidang terbuka untuk publik/ umum melalui media internet (live steaming). Tersedianya layar di ruang sidang membuat publik dapat meliput atau menyaksikan jalannya persidangan.Hakim juga dapat memberitahu segala hak terdakwa. Jadi, penggunaan teleconference dalam pembacaan putusan perkara pidana tidaklah bertentangan dengan Pasal 195 KUHAP.

\section{Daftar Bacaan}

\section{Buku}

M. Yahya Harahap, Pembahasan Permasalahan dan Penerapan KUHAP Penyidikan dan Penuntutan (Sinar Grafika 2000).

M. Yahya Harahap, Pembahasan Permasalahan dan Penerapan KUHAP Penyidikan dan Penuntutan (Sinar Grafika 2017).

Dedi Soermadi, Pengantar Hukum Indonesia (Ind-hill1997).

Jonaedi Efendi Suharto, Panduan Praktis Bila Anda menghadapi Perkara Pidana Mulai Proses Penyelidikan Hingga Persidangan (Prenada Media 2013).

Yesmil Anwar, adang, Sistemm peradilan pidana, konsep, komponen dan pelaksanaannya dalam penegakan hukum di Indonesia (Widya Padjajaran 2009).

\section{Jurnal}

Desak Paramita Brata, Ni Putu Rai Yuliartini, Dewa Gede Sudika Mangku, 'Tinjauan Yuridis Asas Sidang Terbuka Untuk Umum Dalam Penyiaran Proses Persidangan Pidana'(2020) Jurnal Komunitas Yustitia. 
Hafrida, 'Perekaman Proses Persidangan Pada Pengadilan Negeri Ditinjau Dari Aspek Hukum Acara Pidana'(2014) Jurnal Ilmu Hukum.

Dewi Rahmaningsih Nugroho, S. Suteki, 'MembangunBudaya Hukum Persidangan Virtual' (2020) Jurnal Pembangunan Hukum Indonesia, Nomor 3, Fakultas Hukum Universitas Diponogoro.

Sitorus, Diah Vina Laoka, I Gede Artha, I Ketut Sudjayana, 'Proses Persidangan Penyiaran Secara Langsung Live di Televisi Prespektif Hukum Acara Pidana Indonesia' (2018) Jurnal Ilmu Hukum, Fakultas Hukum Universitas Udayana.

\section{Laman}

Hukum online, Putusan pengadilan akan terbuka untuk umum', dalam http://www. hukumonline.com/berita/baca'/h18500/putusan-pengadilan-akan-terbukauntuk-umum, accesed pada 2 juni 2020.

\section{Peraturan Perundang-undangan}

Undang-Undang Nomor 8 Tahun 1981 Kitab Undang-Undang Hukum Acara Pidana ( KUHAP ).

Undang-Undang Nomor 5 Tahun 1986 tentang Peradilan Tata Usaha Neegara.

Undang-Undang Nomor 7 Tahun 1989 tentang Peradilan Agama.

Undang-Undang Republik Indonesia Nomor 35 Tahun 1999 tentang perubahan atas Undang-Undang Nomor 14 Tahun 1970 Tentang ketentuan-ketentuan pokok Kekuasaan Kehakiman.

Undang-Undang Nomor 11 Tahun 2012 tentang Sistem Peradilan Pidana Anak.

Undang - Undang Nomor 48 Tahun 2009 tentang Kekuasan Kehakiman.

Undang-Undang Nomor 32 Tahun 2002 Tentang Penyiaran.

Undang-Undang Nomor 14 Tahun 2008 Tentang Keterbukaan Informasi Publik.

Surat Edaran Mahkamah Agung Nomor 4 Tahun 2012 Tentang perekaman Persidangan. 
Angelia Dwi: Analisis Keabsahan Pembacaan...

--halaman ini sengaja dibiarkan kosong-- 